\title{
Organizational Trust: A Gateway to Psychological Empowerment
}

\author{
Sanad A. Alajmi, Ph.D. \\ Department of Development, Public Authority for Industry, Kuwait \\ E-mail: alajmisanad@hotmail.com
}

Received: Nov. 3, 2016

Accepted: Dec. 16, 2016

Published: January 1, 2017

doi:10.5296/jmr.v9i1.10382

URL: http://dx.doi.org/10.5296/jmr.v9i1.10382

\begin{abstract}
This study investigates the relationship between psychological empowerment of employees and organizational trust within Kuwaiti industrial companies. It focuses on two dimensions of organizational trust; namely, trust in supervisors and trust in the organization. A total of 450 questionnaires were submitted to industrial companies in the Subhan Industrial Area, of which350 were completed. The results indicate that a significant positive correlation exists between psychological empowerment of the employees of these companies and organizational trust. The findings indicate that trust in the supervisor and in the organizationexplains $21.8 \%$ and $13.1 \%$, respectively, of the variation in psychological empowerment. Trust in the supervisor correlates significantly and positively with all dimensions of psychological empowerment whereas trust in the organization correlates significantly and positively with only three dimensions of psychological empowerment; namely, meaning, competence, and self-determination. The study concludes by explaining the limitations involved and suggests future research directions to enhance psychological empowerment and trust in industrial companies in Kuwait.
\end{abstract}

Keywords: psychological empowerment, organizational trust, Kuwait 


\section{Introduction}

With the rapid changes currently sweeping the business environment and the pressures associated with global competition, organizations are forced to adopt practices to obtain maximum benefit from their resources. Because one of these resources is human resources, organizations have realized that focusing on the human element provides a path toward competitive advantage. Thus, organizations have begun to pay special attention to human resources; for example, promoting employee trust in managers and in the organization raises employee empowerment, which ensures employee cooperation and commitment to the policy defined by the organization and gives them the sense of worth that comes with being given responsibilities. Consequently, organizations are constantly seeking ways to expand trust and promote cooperation among employees, especially in work environments in which collective action and teamwork is vital (Melinda et al., 2006; Bruhn, 2001; Mishra, 1996; Tyler and Kramer, 1996).

That said, the study of empowerment has shifted in recent years from the study of managerial intervention in social factors to effectively empower employees to the study of the psychological process employees go through in the empowerment process. Some scholars have noted the importance of subordinate trust to ensure a successful empowerment program (Harari, 2002; Argyris, 1998; Mayer et al., 1995,). The success of psychological empowerment depends on trust between employees on one side and their managers and organization on the other. The present study takes the viewpoint that empowerment is driven by social exchange, which requires managers to abandon reliance on power and control and instead use facilitation and cooperation to connect with their subordinates(Chan et al., 2008).

Although psychological empowerment is linked to a wide range of positive job outcomes, few studies have examined the relationship between psychological empowerment and trust. Thus, research is required to better understand the interrelated topics in this relationship and to fully leverage the opportunity to benefit from such a relationship. The Kuwaiti industrial environment is a prime example of an environment that could benefit from just such a study. In addition, to the best of our knowledge, the relationship between trust and psychological empowerment in Kuwait has yet to be studied in this way.

In recent years, the Kuwaiti government has tried to diversify state revenues to reduce the excessive dependence on oil production, especially given the recent drop in oil prices. The industrial sector is one option that the government seeks to develop as an alternative to oil production. This situation highlights the significance of the present study, which proposes various practices to allow industrial companies to obtain a competitive advantage by optimizing their human resources. The purpose of this study is thus to investigate the relationship between psychological empowerment and organizational trust and, in particular, to determine the level of psychological empowerment and trust felt by employees of Kuwaiti industrial companies. 


\section{Literature review}

\subsection{Psychological empowerment}

Empowerment is the ability of employees to make organizational decisions with a non-negligible degree of flexibility and freedom (Greasley et al., 2008). The concept of empowerment here is in line with traditional management concepts, which focus mainly on the lines of hierarchy within an organization (Greasley et al., 2005). Consequently, several scholars define empowerment as a way to improve the decision-making process at the lower levels of the organization and to enhance staff experience in the workplace (Moye and Henkin, 2005). Bowen and Lawler (1992) define empowerment as a tool to help people make the best decision, whereas Conger and Kanungo (1988) define psychological empowerment in terms of motivational constructs.

Internal and external factors combine to make an individual more dedicated and self-motivated at work. One such internal factor is the sense of psychological empowerment, which enhances predictability, self-esteem, commitment, and job satisfaction. Anintegrative psychological approach to the concept of employee empowerment has been developed based on the hypothesis that, among employees, the psychological experience of power leads to a sense of empowerment (Jha, 2011). Psychological empowerment is seen as a motivational tool in which power and control over internal work serve to stimulate individual employees, eventually increasing employee conviction about workplace effectiveness (Conger and Kanungo, 1988). Thomas and Velthouse (1990) defined the norm of psychological empowerment in terms of a set of four perceptions that reflect the role of employees: meaning (the value of work), efficacy (the ability to do the work), freedom of choice (choice in initiating and organizing procedures), and effectiveness (the ability to influence the results).

Spreitzer (1995) explains the dimensions of empowerment as follows: meaning refers to the value of a work goal or purpose relative to an individual's own ideals or standards; competence or efficacy refers to an individual's belief in his or her capacity to perform activities that require skills; self-determination refers to an individual's perception of choice in initiating and regulating actions; and, finally, impact refers to the extent to which an individual can influence the strategic, administrative, or operating outcomes of their organization.

\subsection{Trust}

Interest is growing in the study and interpretation of the role of trust in organizational processes: one of the most important challenges currently facing managers is to build organizational trust at all levels by allowing employees to participate in the treatment of many organizational problems. Trust is a key element in any positive human relationship because it creates a collaborative environment and gives people a feeling of security and connection (Mishra and Morrissey, 1990). Trust is vital for the integration of management practices, such asempowerment, employee performance, efficiency, capability, and 
organizational commitment. Thus, a high level of trust between employees and supervisors mediates relations towards management practices, such as empowerment (Ertürk, 2012).

Many scholars have proposed definitions for the concept of trust (Lewicki et al., 2006). For example, Mayer and Gavin (2005) believe that trust is "the willingness of a party to be vulnerable to the actions of another party based on the expectation that the other party will perform a particular action important to the trustor, irrespective of the ability to monitor or control that other party." Conversely, Rousseau et al. (1998) identified trust as "a psychological state comprising the intention to accept vulnerability based upon positive expectations of the intentions or behaviors of another". Based on such concepts of trust, most scholars agree on three dimensions of trust: trust in supervisors, trust in colleagues, and trust in the organization. The present study focuses only on trust in supervisors and trust in the organization.

Employee trust in their supervisor would improve employee willingness to accept greater responsibility through empowerment. Andrews (1994) mentioned that trust between employees and managers creates a distinctive atmosphere for empowerment practices which lead to the attainment of goals. Thomas and Velthouse (1990) also pointed out that the results and effectiveness of empowerment do not just rely on individuals to assess their work tasks but also depend on other factors, such as staff interaction with and trust in management, colleagues, and subordinates. An employee that believes that her or she cannot trust their supervisor will have limited desire to contribute to the organization. Obtaining the desired results of psychological empowerment requires raising the level of trust between employee and supervisor, and between staff and top management. Subordinates that trust their supervisor results in improved work performance, boosts organizational citizenship, and encourages subordinates to remain with the organization (Brower et al., 2009; Colquitt et al., 2007). In such cases, the employee makes extra efforts to create value for the organization (Mayer and Gavin, 2005).

Conversely, organizational trust is considered a basic requirement for organizations to keep up with global changes, improve relations, exchange information, opinions, and ideas, and achieve organizational objectives in conjunction with employee objectives. Organizational trust is a key variable in relationships, and human interaction and is strongly related to decision making (Alhawamdeh and Alkasasbeh, 2000). Trust is a strong predictor of individual behavior and is related to job satisfaction, the development of competitive performance at various organizational levels, and stability when confronted with uncertainty (Alsaudi, 2005). In addition, organizational trust is expected to relate to other factors that are important for the effective functioning of organizations in today's competitive business environment (Brashear et al., 2003; Parnell \& Crandall 2003).

Covey (1998) stated that the only way to exploit empowerment is by promoting trust in the culture of the organization. In addition, psychological empowerment is linked to organizational effectiveness when employees work in an environment of trust. Moreover, Andrews (1994) claimed that lack of trust within an organization may lead to failure embodied by the formation of subtle and invisible barriers that thwart efforts aimed at 
employee success. Based on these results, we can say that organizational trust is an important gateway to the culture of empowerment, which depends on the composition of trust between the managers and employees. The expansion of this culture forms the base for employee participation in decision making. Empowerment and trust lead to improved performance, facilitate the flow of information, and increase opportunities for dialogue and understanding, thereby allowing employees to participate in organizational vision.

Numerous studies have discussed the relationship between trust and empowerment. In one such study, Gomez and Rosen (2001) demonstrated a positive correlation between the level of trust between supervisors and subordinates and the policies empowering subordinates. They found that trust improves such relationships and increases supervisor willingness to empower their subordinates. In addition, Jiang et al. (2011) showed that the relationship between supervisors and subordinates affects the performance of the latter, and that trust improves such relationships and increases supervisor willingness to empower their subordinates. Chan et al. (2008) confirmed that the effectiveness of psychological empowerment to influence employee behavior depends on the level of subordinate trust in their supervisors. Some of these studies helped clarify the role of organizational trust prior to employee empowerment. For example, Ergeneli et al. (2007) explained the impact of organizational trust by invoking only three dimensions of psychological empowerment: meaning, competence, and impact, whereas Barton and Barton (2011) revealed the positive effect of organizational trust on all psychological dimensions of empowerment. In contrast, other studies confirmed that organizational trust is one of the most important results of psychological empowerment because the consolidation of a sense of empowerment among employees increases their sense of being an essential part of the organization and gives them more confidence. Therefore, the more psychologically empowered employees feel, especially regarding their sense of impact, the higher is their perceived level of organizational trust (Men, 2011; Hamed, 2010).

Consequently, we expect that psychological empowerment will be stronger among employees who have greater trust in their supervisors and organization. In other words, a higher level of employee trust toward their supervisors and organization would strengthen the psychological empowerment of employees. Thus, the following hypothesis may be formulated:

\section{H. Employee trust correlates positively with psychological empowerment.}

This main hypothesis is divided into the following two sub-hypotheses:

Ha. Employee trust in their supervisor correlates positively with psychological empowerment.

Hb. Employee trust in their organization correlates positively with psychological empowerment. 


\section{Macrothink}

\section{Methods}

\subsection{Sample and Procedure}

To empirically test the proposed hypotheses, data were collected from a simple random sampling of industrial companies in the Subhan Industrial Area, Kuwait. Data were acquired via a structured questionnaire, of which 450 were sent out, each accompanied with a cover letter to explain the purpose of the survey and that participation was voluntary and confidential. To ensure anonymity, respondents were asked to return the completed questionnaires directly to the research assistant. Of the 450 questionnaires sent, 350 completed questionnaires were returned, for a response rate of $78 \%$. Some demographic data were collected, such as gender, age, educational level, and work experience. The sample was $60 \%$ male and respondents ranged in age from 21 to 60 years old, with an average of 32 years old (standard deviation of 4.4 years). The respondents had worked for their companies from 2 to 29 years, with an average of 10 years (standard deviation of 5 years), and $40.3 \%$ of them had a university degree or higher degree ( $\mathrm{PhD}$ or master).

\subsection{Measures}

Considering the objective and design of the study, we used standard instruments containing closed-ended questions to extract information. All items were measured on a five-point Likert-type scale where 1 indicates "strongly disagree" and 5 indicates "strongly agree." In this study, psychological empowerment was measured with 12 items and four dimensions: meaning, competence, self-determination, and impact (Spreitzer, 1995). Trust was measured by using the scale of Nyhan and Marlowe (1997), which consists of eight items that measure employee trust in their immediate supervisor and four items that measure employee attitude toward their internal organization. Finally, negative statements were converted by using SPSS V.23.

\section{Results}

\subsection{General Information}

Table 1 lists the characteristics of the participants in the study. 
Table 1. Characteristics ofstudy participants.

\begin{tabular}{|c|c|c|c|}
\hline Variable & Category & Number & Percent \\
\hline \multirow{3}{*}{ Gender } & Male & 210 & $60 \%$ \\
\hline & Female & 140 & $40 \%$ \\
\hline & Total & 350 & $100 \%$ \\
\hline \multirow{8}{*}{ Age } & Category & Number & Percent \\
\hline & Less than 24 Years & 25 & $7.1 \%$ \\
\hline & 25 to 30 Years & 79 & $22.6 \%$ \\
\hline & 31 to 35 Years & 98 & $28.0 \%$ \\
\hline & 36 to 40 Years & 69 & $19.7 \%$ \\
\hline & 41 to 45 Years & 56 & $16.0 \%$ \\
\hline & 46 years and above & 23 & $6.6 \%$ \\
\hline & Total & 350 & $100 \%$ \\
\hline \multirow{6}{*}{ Educational Level } & Category & Number & Percent \\
\hline & High school or less & 94 & $26.9 \%$ \\
\hline & Diploma degree & 115 & $32.9 \%$ \\
\hline & University degree & 105 & $30.0 \%$ \\
\hline & Higher degree & 36 & $10.3 \%$ \\
\hline & Total & 350 & $100 \%$ \\
\hline \multirow{8}{*}{ Workexperience } & Category & Number & Percent \\
\hline & Less than 5 years & 55 & $15.7 \%$ \\
\hline & 5 to 10 years & 141 & $40.3 \%$ \\
\hline & 11 to 15 years & 101 & $28.9 \%$ \\
\hline & 16 to 20 years & 30 & $8.6 \%$ \\
\hline & 21 to 25 years & 9 & $2.6 \%$ \\
\hline & More than 25 years & 14 & $4.0 \%$ \\
\hline & Total & 350 & $100 \%$ \\
\hline
\end{tabular}

\subsection{Reliability Analysis}

Table 2 gives the reliability indices for the factors of psychological empowerment and the dimensions of trust. 


\section{Ml Macrothink}

Journal of Management Research ISSN 1941-899X 2017, Vol. 9, No. 1

Table 2. Reliability indices for factors of psychological empowerment and dimensions of trust

\begin{tabular}{|l|c|c|}
\hline Scale & Number of items & Cronbach'salpha \\
\hline Meaning & 3 & 0.80 \\
\hline Competence & 3 & 0.87 \\
\hline Self-determination & 3 & 0.74 \\
\hline Impact & 3 & 0.85 \\
\hline Psychological empowerment (overall) & 12 & 0.85 \\
\hline Trust in supervisors & 8 & 0.93 \\
\hline Internal organizational trust & 4 & 0.89 \\
\hline Organizational trust (overall) & 12 & 0.93 \\
\hline Valid $\boldsymbol{n}$ & 350 & \\
\hline
\end{tabular}

Cronbach's alpha for the factors of psychological empowerment (organizational trust)range from 0.74 to 0.87 ( 0.89 to 0.93 ). Cronbach's alpha provides a lower bound for the reliability of the variables used to construct the model; its overall range from 0.74 to 0.93 clearly exceeds the minimum acceptable level of 0.70 (George and Mallery, 2003).

\subsection{Descriptive Statistics of Variables}

Table 3 gives the means, standard deviations, and percentages for all variables.

Table 3. Descriptive statistics for all variables

\begin{tabular}{|l|c|c|c|c|c|c|c|c|}
\hline \multirow{2}{*}{ Measure } & \multicolumn{9}{|c|}{ PsychologicalEmpowerment } & \multicolumn{3}{c|}{ Level of Trust } \\
\cline { 2 - 9 } & ME & CO & SED & I & All & TS & IT & All \\
\hline Mean & 3.7 & 4.1 & 3.5 & 3.1 & 3.6 & 3.9 & 3.22 & 3.7 \\
\hline St. dev. & 0.96 & 0.84 & 0.92 & 0.92 & 0.7 & 0.86 & 0.98 & 0.8 \\
\hline SD & $7.6 \%$ & $2.4 \%$ & $3.8 \%$ & $6.7 \%$ & $5.1 \%$ & $2.7 \%$ & $9.6 \%$ & $5.0 \%$ \\
\hline D & $9.4 \%$ & $5.7 \%$ & $21.8 \%$ & $23.6 \%$ & $15.1 \%$ & $9.5 \%$ & $16.8 \%$ & $11.9 \%$ \\
\hline DK & $12.0 \%$ & $8.1 \%$ & $11.1 \%$ & $23.9 \%$ & $13.8 \%$ & $12.5 \%$ & $25.4 \%$ & $16.8 \%$ \\
\hline A & $45.4 \%$ & $43.6 \%$ & $42.4 \%$ & $40.2 \%$ & $42.9 \%$ & $41.4 \%$ & $37.6 \%$ & $40.1 \%$ \\
\hline SA & $25.5 \%$ & $40.2 \%$ & $20.9 \%$ & $5.6 \%$ & $23.0 \%$ & $34.0 \%$ & $10.6 \%$ & $26.2 \%$ \\
\hline \multicolumn{1}{|c|}{ Total } & $\mathbf{1 0 0 \%}$ & $\mathbf{1 0 0} \%$ & $\mathbf{1 0 0} \%$ & $\mathbf{1 0 0} \%$ & $\mathbf{1 0 0} \%$ & $\mathbf{1 0 0 \%}$ & $\mathbf{1 0 0 \%}$ & $\mathbf{1 0 0} \%$ \\
\hline
\end{tabular}

SD: strongly disagree; D:disagree, DK: don’t know, A:agree, SA:strongly Agree

ME: meaning; CO: competence; SED: self-determination; I:impact; TS: trust in supervisors;

IT: internal-organizational trust 


\subsection{Correlations Tests}

\subsubsection{Correlations between main variables}

Table 4.1 gives the correlation matrix for the main variables.

Table 4.1. Correlation matrix for main variables

\begin{tabular}{|l|c|c|c|c|}
\hline \multicolumn{1}{|c|}{ Variables } & $\mathbf{1}$ & $\mathbf{2}$ & $\mathbf{3}$ & $\mathbf{4}$ \\
\hline Psychological empowerment & 1 & & - & \\
\hline Organizational trust & $0.480^{* *}$ & $0.666^{* *}$ & $0.557^{* *}$ & 1 \\
\hline
\end{tabular}

**Correlation is significant at 0.01 level (two-tailed).

Table 4.1 reveals a highly significant and positive correlation between the variables ( $p$-value $<0.01)$. The correlation coefficients varyfrom0.48to 0.67 , as shown in the table.

\subsubsection{Correlations between minor variables}

Table 4.2 gives the correlation matrix for the minor variables.

Table 4.2. Correlation matrix for minor variables

\begin{tabular}{|l|c|c|c|c|c|c|}
\hline Variables & ME & CO & SED & I & TS & IT \\
\hline ME & 1 & & & & & \\
\hline CO & $0.59^{* *}$ & 1 & & & & \\
\hline SED & $0.409^{* *}$ & $0.43^{* *}$ & 1 & & & \\
\hline I & $0.309^{* *}$ & $0.11^{*}$ & $0.40^{* *}$ & 1 & & \\
\hline TS & $0.39^{* *}$ & $0.43^{* *}$ & $0.35^{* *}$ & $0.20^{* *}$ & 1 & \\
\hline IT & $0.36^{* *}$ & $0.36^{* *}$ & $0.26^{* *}$ & 0.09 & $0.59^{* *}$ & 1 \\
\hline
\end{tabular}

** Correlation is significant at 0.01 level (two-tailed).

* Correlation is significant at 0.05 level (two-tailed).

ME: meaning; CO: competence; SED: self-determination; I: impact; TS: trust in supervisors; IT: internal-organizational trust

The data were analyzed by using an inter correlation matrix to show the correlations between the dimensions of the dependent variable (psychological empowerment) and each dimension of the independent variable (level of trust) in addition to the correlations between the dimensions of the independent variables. The correlation matrix shows that significant positive correlations exist for a significance level set at $1 \%$ between the level of employee trust in their supervisor and the dimensions of psychological empowerment, whereas significant positive correlations exist for a significance level set at $1 \%$ between level of employee trust in the organization and three dimensions of psychological empowerment: 


\section{Macrothink}

Journal of Management Research

ISSN 1941-899X

2017, Vol. 9, No. 1

meaning, competence, and self-determination. Employee trust in the organization is not correlated with the fourth dimension of psychological empowerment (i.e., impact) because the significance is greater than 0.05 , as shown in Table 4.2.

\section{Hypotheses to Test}

Psychological empowerment is expected to be stronger for employees who have more trust in their supervisors and organization. Thus, employees with a higher level of trust in their supervisors and organization should have a stronger sense of psychological empowerment. The hypothesis of the study maybe formulated as follows:

H1.Employee trust correlates positively with psychological empowerment.

This study uses a regression analysis to test the hypothesis. The regression hypothesis is supported if the standardized coefficients of the regression are nonzero and statistically significant, which would indicate that the relevant independent variables significantly influence the dependent variables. The results of the regression analysis for the independent variables and the dependent variable are illustrated in Tables 5.1-5.3.

Table 5.1. Model summary

\begin{tabular}{|c|l|c|c|l|}
\hline Model & $\boldsymbol{R}$ & $\boldsymbol{R}^{\mathbf{2}}$ & Adjusted $\boldsymbol{R}^{\mathbf{2}}$ & $\begin{array}{l}\text { Std. error of } \\
\text { estimate }\end{array}$ \\
\hline 1 & 0.480 & 0.230 & 0.228 & 6.98 \\
\hline
\end{tabular}

Table 5.2. Results of analysis of variance

\begin{tabular}{|c|c|c|c|c|c|c|}
\hline \multicolumn{2}{|c|}{ Model } & $\begin{array}{c}\text { Sum of } \\
\text { squares }\end{array}$ & df & Mean square & F & Sig. \\
\hline \multirow{3}{*}{1} & Regression & 5073.92 & 1 & 5073.92 & 104.03 & 0.000 \\
\cline { 2 - 7 } & Residual & 16973.27 & 348 & 48.774 & & \\
\cline { 2 - 7 } & Total & $\mathbf{2 2 0 4 7 . 1 9}$ & $\mathbf{3 4 9}$ & & \\
\hline
\end{tabular}

Table 5.3. Coefficients

\begin{tabular}{|c|c|c|c|c|c|c|}
\hline \multirow{2}{*}{\multicolumn{2}{|c|}{ Model }} & \multicolumn{2}{|c|}{$\begin{array}{c}\text { Unstandardized } \\
\text { coefficients } \\
\end{array}$} & \multirow{2}{*}{$\begin{array}{c}\text { Standardized } \\
\text { coefficients }\end{array}$} & \multirow[t]{2}{*}{$\mathbf{t}$} & \multirow[t]{2}{*}{ Sig. } \\
\hline & & B & Std. Error & & & \\
\hline \multirow{2}{*}{1} & (Constant) & 26.15 & 1.76 & & 14.9 & 0.000 \\
\hline & Level of Trust & 0.393 & 0.04 & 0.480 & 10.2 & 0.000 \\
\hline
\end{tabular}

The regression analysis of the variables for hypothesis $\mathrm{H} 1$ reveals a positive and significant correlation between the level of employee trust and psychological empowerment $(R=0.480$, sig. $<0.01)$. In other words, greater employee trust in their organization leads to greater psychological empowerment. The results shown in Table 5.2 suggest that the model is statistically significant $(F=104.03$, sig. $<0.01)$, which means that employee trust can predict psychological empowerment. The results shown in Table 5.3 indicate that employee trust 
significantly and positively correlates with psychological empowerment $(\beta=0.480$, sig. $<0.01)$. According to the adjusted $R^{2}$ (Table 5.1), employee trust explains $22.8 \%$ of the variance in psychological empowerment.

Furthermore, the main hypothesis may be divided into the two following sub-hypotheses:

Ha. Employee trust in their supervisor correlates positively with psychological empowerment.

Hb. Employee trust in their organizations correlates positively with psychological empowerment.

We begin by discussing sub-hypothesis Ha. The results of the regression analysis for the independent variable (employee trust in their supervisor)and the dependent variable (psychological empowerment) are given in Tables 6.1-6.3.

Table 6.1. Model summary

\begin{tabular}{|c|c|c|c|c|}
\hline Model & $\mathbf{R}$ & $\boldsymbol{R}^{\mathbf{2}}$ & Adjusted $\boldsymbol{R}^{\mathbf{2}}$ & $\begin{array}{c}\text { Std. error of } \\
\text { estimate }\end{array}$ \\
\hline 2 & 0.469 & 0.220 & 0.218 & 7.030 \\
\hline
\end{tabular}

Table 6.2: Results of analysis of variance.

\begin{tabular}{|c|l|c|c|c|c|c|}
\hline \multicolumn{2}{|c|}{ Model } & $\begin{array}{c}\text { Sum of } \\
\text { squares }\end{array}$ & df & $\begin{array}{c}\text { Mean } \\
\text { square }\end{array}$ & F & Sig. \\
\hline \multirow{3}{*}{2} & Regression & 4847.96 & 1 & 4847.96 & 98.09 & 0.000 \\
\cline { 2 - 7 } & Residual & 17199.23 & 348 & 49.42 & & \\
\cline { 2 - 7 } & Total & $\mathbf{2 2 0 4 7 . 1 9}$ & $\mathbf{3 4 9}$ & & \\
\hline
\end{tabular}

Table 6.3: Coefficients.

\begin{tabular}{|c|l|c|c|c|c|c|}
\hline \multicolumn{2}{|c|}{ Model } & \multicolumn{2}{|c|}{$\begin{array}{c}\text { Unstandardized } \\
\text { coefficients }\end{array}$} & $\begin{array}{c}\text { Standardized } \\
\text { coefficients }\end{array}$ & \multirow{2}{*}{ t } & \multirow{2}{*}{ Sig. } \\
\cline { 3 - 5 } \multicolumn{2}{c|}{} & B & Std. error & Beta & & \\
\hline \multirow{2}{*}{2} & (Constant) & 26.471 & 1.773 & & 14.93 & 0.000 \\
\cline { 2 - 6 } & Trust in the supervisor & 0.544 & 0.055 & 0.469 & 9.90 & 0.000 \\
\hline
\end{tabular}

The regression analysis of the variables for sub-hypothesis Ha reveals that a positive and significant correlation exists between the level of employee trust in their supervisor and psychological empowerment $(R=0.469$, sig. $<0.01)$. In other words, greater employee trust in their supervisor leads to greater psychological empowerment. The results of Table 6.2 suggests that the model is statically significant $(F=98.01$, sig. $<0.01)$, which means that employee trust in their supervisor can predict psychological empowerment. Table 6.3 shows that employee trust in the supervisor significantly and positively correlates with psychological empowerment $(\beta=0.469$, sig. $<0.01)$. According to the adjusted $R^{2}$ (Table 6.1 ), 
employee trust in the supervisor explains $21.8 \%$ of the variance in psychological empowerment.

Table 6.4 gives the results of the structural equation modeling (SEM) analysis of the relationship between employee trust in their supervisor and the dimensions of psychological empowerment.

Table 6.4. Results of SEM analysis of the relationship between employee trust in their supervisor and the dimensions of psychological empowerment: standardized regression weights

\begin{tabular}{|c|c|c|c|c|c|}
\hline $\begin{array}{c}\text { Dependent } \\
\text { variables } \\
\end{array}$ & $\begin{array}{c}\text { Independent } \\
\text { variable }\end{array}$ & $\begin{array}{c}\text { Standardized } \\
\text { coefficients }\end{array}$ & $t$ & Sig. & $\begin{array}{l}\text { Squared multiple } \\
\text { correlation }\end{array}$ \\
\hline Meaning & \multirow{4}{*}{$\begin{array}{l}\text { Trust in } \\
\text { supervisor }\end{array}$} & 0.393 & 7.98 & 0.000 & 0.041 \\
\hline Competence & & 0.427 & 8.81 & 0.000 & 0.122 \\
\hline Self-determination & & 0.349 & 6.96 & 0.000 & 0.182 \\
\hline Impact & & 0.202 & 3.86 & 0.000 & 0.154 \\
\hline
\end{tabular}

The SEM analysis reveals that trust in the supervisor is significantly and positively correlated with all dimensions of psychological empowerment; namely, meaning, competence, self-determination, and impact, because the respected standardized coefficients are $\beta_{1}=0.393$, $\beta_{2}=0.427, \beta_{3}=0.349$, and $\beta_{4}=0.202$. Employee trust in their supervisor explains about $4.1 \%$, $12.2 \%, 18.2 \%$, and $15.4 \%$ of the variance in these four dimensions, respectively, as indicated by the squared multiple correlations. Employee trust in their supervisor most strongly influences competence $\left(\beta_{2}=0.427\right)$ and meaning $\left(\beta_{1}=0.393\right)$.

We now consider now sub-hypothesis $\mathrm{Hb}$. Tables 7.1-7.3 give the results of the regression analysis for the independent variable (level of employee trust in their organization) and the dependent variable (psychological empowerment).

Table 7.1. Model summary

\begin{tabular}{|c|c|c|c|c|}
\hline Model & $\mathbf{R}$ & $\boldsymbol{R}^{\mathbf{2}}$ & Adjusted $\boldsymbol{R}^{\mathbf{2}}$ & $\begin{array}{c}\text { Std. error of } \\
\text { estimate }\end{array}$ \\
\hline 3 & 0.366 & 0.134 & 0.131 & 7.408 \\
\hline
\end{tabular}

Table 7.2. Results of analysis of variance

\begin{tabular}{|c|l|c|c|c|c|c|}
\hline \multicolumn{2}{|c|}{ Model } & Sum of squares & df & Mean square & F & Sig. \\
\hline \multirow{3}{*}{3} & Regression & 2950.91 & 1 & 2950.91 & 53.78 & 0.000 \\
\cline { 2 - 7 } & Residual & 19096.28 & 348 & 54.87 & $\mathbf{3 4 9}$ & \\
\cline { 2 - 7 } & Total & $\mathbf{2 2 0 4 7 . 1 9}$ & $\mathbf{3}$ & \\
\hline
\end{tabular}


Table 7.3. Coefficients

\begin{tabular}{|c|c|c|c|c|c|c|}
\hline & \multirow[t]{2}{*}{ Model } & \multicolumn{2}{|c|}{$\begin{array}{c}\text { Unstandardized } \\
\text { coefficients }\end{array}$} & \multirow{2}{*}{$\begin{array}{c}\text { Standardized } \\
\text { coefficients } \\
\text { Beta }\end{array}$} & \multirow[t]{2}{*}{$t$} & \multirow[t]{2}{*}{ Sig. } \\
\hline & & B & Std. Error & & & \\
\hline \multirow[b]{2}{*}{3} & (Constant) & 34.086 & 1.361 & & 25.05 & 0.000 \\
\hline & $\begin{array}{l}\text { Level of trust in } \\
\text { the organization }\end{array}$ & 0.740 & 0.101 & 0.366 & 7.33 & 0.000 \\
\hline
\end{tabular}

The regression analysis of the variables for sub-hypothesis $\mathrm{Hb}$ reveals a positive and significant correlation between the level of employee trust in the organization and psychological empowerment $(R=0.366$, sig. $<0.01)$. In other words, greater employee trust in the organization leads to greater psychological empowerment. The results given in Table 7.2 suggest that the model is statically significant $(F=53.78$, sig. $<0.01)$ which means that employee trust in the organization can predict psychological empowerment. The results given in Table 7.3 show that employee trust in the organization significantly and positively correlates with psychological empowerment $(\beta=0.366$, sig. $<0.01)$. According to the adjusted $R^{2}$ (Table 7.1) employee trust in the organization explains $13.1 \%$ of the variance in psychological empowerment.

Table 7.4 presents the results of an SEM analysis of the relationship between employee trust in the organization and the dimensions of psychological empowerment.

Table 7.4. Results of SEM analysis of the relationship between employee trust in the organization and the dimensions of psychological empowerment: standardized regression weights

\begin{tabular}{|c|c|c|c|c|c|}
\hline $\begin{array}{c}\text { Dependent } \\
\text { variables } \\
\end{array}$ & $\begin{array}{c}\text { Independent } \\
\text { variable } \\
\end{array}$ & $\begin{array}{c}\text { Standardized } \\
\text { coefficients }\end{array}$ & $t$ & Sig. & $\begin{array}{l}\text { Squared multiple } \\
\text { correlation }\end{array}$ \\
\hline Meaning & \multirow{4}{*}{$\begin{array}{c}\text { Trust in } \\
\text { organization }\end{array}$} & 0.363 & 7.289 & 0.000 & 0.008 \\
\hline Competence & & 0.358 & 7.169 & 0.000 & 0.066 \\
\hline Self-determination & & 0.256 & 4.952 & 0.000 & 0.128 \\
\hline Impact & & 0.091 & 1.705 & 0.088 & 0.132 \\
\hline
\end{tabular}

An SEM analysis reveals that trust in the organization correlates significantly and positively with three dimensions of psychological empowerment; namely, meaning, competence, and self-determination, because the standardized coefficients are $\beta_{1}=0.363, \beta_{2}=0.358$, and $\beta_{3}=$ 0.256 . As indicated by the squared multiple correlations, employee trust in the organization explains about $1 \%, 6.6 \%$, and $12.8 \%$ of the variance in these dimensions, respectively. No statistically significant correlation appears between trust in the organization and impact $\left(\beta_{4}=\right.$ 0.091, sig. > 0.05).

\section{Conclusions and recommendations}

This study focuses on industrial companies in Kuwait and explores the correlation between psychological empowerment of employees and employee trust in their supervisors and organization. The results show that employee trust correlates significantly with psychological 
empowerment. This result emphasizes the importance of trust to the success of empowerment programs in organizations (Harari, 2002; Argyris, 1998; Covey 1998; Mayer et al., 1995).

This study examines two aspects of employee trust: employee trust in their supervisor and employee trust in the organization. Employee trust in their supervisor is found to correlate significantly and positively with psychological empowerment and explains $21.8 \%$ of the variance in psychological empowerment. Moreover, employee trust in the supervisor is significantly and positively correlated to all dimensions of psychological empowerment: meaning, competence, self-determination, and impact. This result is consistent with previous research conducted in other contexts that provides evidence that employee trust is an antecedent of psychological empowerment. (Jian et al., 2009; Chan et al., 2008; Gomez and Rosen, 2001; Andrews, 1994)

The results also reveal a positive and significant correlation between employee trust in the organization and psychological empowerment. Greater employee trust in the organization leads to greater psychological empowerment. Employee trust in the organization explains $13.1 \%$ of the variance in psychological empowerment. Trust in the organization is significantly and positively correlated to three dimensions of psychological empowerment: meaning, competence, and self-determination. This result is consistent with that of Ergeneli et al. (2007)only on two dimensions of psychological empowerment (i.e., meaning and competence), and with the result of Barton and Barton (2011)only on three dimensions, where there study revealed that organizational trust correlated positively with all dimensions of psychological empowerment. The reason could be back behind the decline in the relative importance of the impact dimension to the employees' self-confidence, making them more dependent on themselves, because they believe that the experiences that they own enough to do the assigned work.

The results of this study also clarify that employee trust in their supervisor is more strongly correlated with psychological empowerment than with organizational trust. Therefore, supervisors who display trust create high levels of psychological empowerment in their subordinates. Thus, both employee trust in their supervisor and in the organization promote psychological empowerment, which means that industrial companies should continue to promote psychological empowerment by developing trust between employees and their supervisors on the one hand, and between employees and their organization on the other. In addition, industrial companies should create an organizational culture that supports the development and dissemination of awareness and knowledge of the concept of psychological empowerment and its benefits for both supervisors and subordinates. This would facilitate decentralized decision making and enhance the empowerment process by giving employees more authority in solving problems.

\section{Limitation and future research}

This study has a number of limitations, the most important of which is that it neglects a particular industrial sector and includes more companies from other sectors (this resulted from the distribution of respondents to the survey questionnaire), which makes it difficult to generalize the results of the study to various industrial companies. Future research seeking to 
determine a relationship between psychological empowerment and employee trust should expand on the present study by comparing different sectors. Also, this research does not address the influence of demographic variables, such a sage and years of experience. Future research should explore the link between psychological empowerment and demographics variables, which would improve our understanding of how to enhance psychological empowerment of employees. Finally, because this research concentrates on how trust affects psychological empowerment, future research should examine other variables, such as organizational justice, that may mediate this relationship.

\section{References}

Alhawamdeh, Nidal, \& Alkasasbeh, Mohammed (2000). The impact of organizational trust and participation in decision-making on the satisfaction of teaching in Mutah University faculty members. Muta for Research and Studies, 15(6), 141-168.

Alsaudi, Ahmed Musa (2005). The relationship between organizational trust and job satisfaction among workers in the Jordanian ministries. Management Science Studies, 32(1), 100-114.

Andrews, G.M. (1994). Mistrust, the hidden obstacle to empowerment.HR Magazine, 39, 66-70.

Argyris, C. 1998. Empowerment: The Emperor's New Clothes. Harvard Business Review (May-June): 8-105.

Barton, H., \& Barton, L. C. (2011). Trust and psychological empowerment in the Russian work context. Human Resource Management Review, 21(3), 201-208. http://dx.doi.org/10.1016/j.hrmr.2011.02.001

Bowen, D. E., \& Lawler, E. E. (1992). The Empowerment of Service Workers: What, Why, How, and When. Sloan Management Review, 33(3), 31-39.

Brashear, T.G., Boles J.S., Bellenger D.N., \& Brooks C.M. (2003).An Empirical Test of Trust-building Processes and Outcomes in Sales Manager -Salesperson Relationships. Academy of Marketing Science Journal, 189-200.http://dx.doi.org/10.1177/0092070302250902

Brower, H. H., Lester, S. W., Korsgaard, M. A., \& Dinen, B. R. (2009). A Closer Look at Trust between Managers and Subordinates: Understanding the Effects of Both Trusting and Being Trusted on Subordinate Outcomes. Journal of Management, 35(2), 327-347. http://dx.doi.org/10.1177/0149206307312511

Bruhn, J. (2001). Trust and the Health of Organizations. Kluwer Academic/Plenum Publishers, New York, NY. http://dx.doi.org/10.1007/978-1-4615-0739-0

Chan, Y. H., Taylor, R. R., \& Markham, S. (2008). The Role of Subordinates' Trust in a Social Exchange-driven Psychological Empowerment Process. Journal of Managerial Issues, 20(4), 444-467. 
Colquitt, J. A., Scott, B. A., \& Le Pine J. A. (2007). Trust, Trustworthiness, and Trust Propensity: A Meta-analytic Test of Their Unique Relationships with Risk Taking and Job Performance. Journal of Applied Psychology, 92, 902-927.http://dx.doi.org/10.1037/0021-9010.92.4.909

Conger, J., \& Kanungo, R. (1988). The empowerment process: integrating theory and practice. Academy of Management Review, 13(3), 471-482. http://dx.doi.org/10.1037/0033-2909.131.2.241

Covey, S.R. (1998). Servant leadership from the inside out.In Spears, L. (Ed.), Insights on Leadership (pp. 11-18). New York: Wiley.

Ergeneli, A., Ari, G.S., \& Metin, S. (2007). Psychological empowerment and its relationship to trust in immediate managers. Journal of Business Research, 60(1), 41-49. http://dx.doi.org/10.1016/j.jbusres.2006.09.012

Ertürk, Alper (2012) Linking Psychological Empowerment to Innovation Capability: Investigating the Moderating Effect of Supervisory Trust. International Journal of Business and Social Science, 3(14), 153-165.

George, D., \& Mallery, P. (2003).SPSS for Windows step by step: A simple guide and reference. 11.0 update (4th ed.). Boston: Allyn \& Bacon.

Gomez, C., \& Rosen, B. (2001). The Leader-Member Exchange a Link between Managerial Trust and Employee Empowerment. Group \& Organization Management, 26(1), 5369.http://dx.doi.org/10.1177/1059601101261004

Greasley, K., Bryman, A., Dainty, A., Price, A., Naismith, N., \& Soetanto, R. (2008).Understanding empowerment from an employee perspective. Team Performance Management, 14(1/2), 39-55. http://dx.doi.org/10.1108/13527590810860195

Greasley, K., Bryman, A., Dainty, A., Price, A., Soetanto, R., \& King, N. (2005).Employee perceptions of empowerment. Employee Relations, 27(4), 354-368.http://dx.doi.org/10.1108/01425450510605697

Hamed, S. S. (2010). Antecedents and consequences of employees empowerment. Management Review: An International Journal, 5(1), 64-94.

Harari, O. (2002). The Trust Factor. Public Management, 84(8), 6-10.

Jha, Sumi (2011). Influence of Psychological Empowerment on Affective and Normative and Continuance commitment: A study in Indian IT industry. Journal of Indian Business Research, 3(4), 263-282. http://dx.doi.org/10.1108/17554191111180582

Jiang, C. X., Chua, R. Y. J., Kotabe, M., \& Murray, J. Y. (2011). Effects of cultural ethnicity, firm size, and firm age on senior executives' trust in their overseas business partners: Evidence from China. Journal of International Business, 42(9), 1150-1173.http://dx.doi.org/10.1057/jibs.2011.35 
Lewicki, R. J., Tomlinson, E., \& Gillespie, N. (2006). Models of interpersonal trust development: Theoretical approaches, empirical evidence, and future directions. Journal of Management, 32(6), 991-1022.http://dx.doi.org/10.1177/0149206306294405

Mayer, R. C., \& Gavin, M. B. (2005). Trust in Management and Performance: Who Minds the Shop while the Employees Watch the Boss?. Academy of Management Journal, 48(5), 874-888.http://dx.doi.org/10.5465/AMJ.2005.18803928

Mayer, R. C., Davis J. H., \& Schoorman F. D. (1995). An Integrative Model of Organizational Trust. Academy of Management Review 20(3), 709-734.

Melinda J. Moye Alan B. Henkin. (2006). Exploring associations between employee empowerment and interpersonal trust in managers. Journal of Management Development, 25(2), 101- 117. http://dx.doi.org/10.1108/02621710610645108

Men, L. R. (2011). How employee empowerment influences organization employee relationship in China. Public Relations Review 37(4), 435-437. http://dx.doi.org/10.1016/j.pubrev.2011.08.008.

Mishra, A. (1996). Organizational responses to crisis: the centrality of trust, in Kramer, R. and Tyler, T. (Eds), Trust in Organizations: Frontiers of Theory and Research, Sage Publications Inc., Thousand Oaks, CA, pp. 261-87.

Mishra, J., \& Morrissey, M.A. (1990). Trust in employee/employer relationships: A survey of west Michigan managers. Public Personnel Management, 19(4), 443-485. http://dx.doi.org/10.1177/009102609001900408

Moye, M. J., \& Henkin, A. B. (2005). Teacher-Principal Relationships: Exploring Linkages between Empowerment and Interpersonal Trust. Journal of Educational Administration, 43(3), 260-277. http://dx.doi.org/10.1108/09578230510594796

Nyhan, R.C., \& Marlowe, HA (1997). Development and Psychometric Properties of Organisational Trust Inventory. Evaluation Review 21(5), 614-635. http://dx.doi.org/10.1177/0193841X9702100505

Parnell, J. A., \& Crandall, W. (2003). Propensity for Participative Decision-making, Job Satisfaction, Organisational Commitment and Intention to Leave among Egyptian Managers. Multinational Business Review, 11(1), 45-65. http://dx.doi.org/10.1108/1525383X200300003

Rousseau, D., Sitkin, S., Burt, R., \& Camerer, C. (1998). Not so different after all: A cross-discipline view of trust. Academy of Management Review, 23(3), 393-404. http://dx.doi.org/10.5465/AMR.1998.926617

Spreitzer, G. M. (1995). Psychological empowerment in the workplace: Dimensions, measurement, and validation. Academy of Management Journal, 38(5), 1442-1465. http://dx.doi.org/10.2307/256865 


\section{Macrothink}

Journal of Management Research ISSN 1941-899X 2017, Vol. 9, No. 1

Thomas, K.W., \& Velthouse, B. A. (1990). Cognitive elements of empowerment: An "interpretive" model of intrinsic task motivation. Academy of Management Review, 15(4), 666-681.

Tyler, T. and Kramer, R. (1996).Whither trust?, in Kramer, R. and Tyler, T. (Eds), Trust in Organizations: Frontiers of Theory and Research, Sage Publications, Inc., Thousand Oaks, CA, pp. 1-15. https://doi.org/10.4135/9781452243610.n1 